\title{
A REAFFIRMATION OF RIGOROUS SCHOLARLY INTEGRITY
}

As we launch issue two of the 2018 African Studies Review, the second under the new editorial collective, we turn our attention to scholarly practice and to safeguarding the integrity of scholarly review. Over the past several months, the editorial leadership team has grappled with the shifting terrain of scholarly production, implementing several new policies and procedures that we esteem will improve the contributor experience and assist us all in tackling some of the more pervasive problems inherent in scholarly publishing.

Since the addition of a full-time professional Managing Editor, Kathryn Salucka, based in the African Studies Association (ASA) headquarters, we hope that many of you have already detected improvements in responsiveness by our editorial team, the smoothness of operational liaison with our publisher, Cambridge University Press, and enhanced community outreach. Perhaps the most important of these improvements is the introduction of an additional step in the preparation of book and film reviews and review essays. Starting in 2018, all reviewers will receive proofs of their work prior to final publication and will have the ability to approve those proofs and any suggested edits or changes. Further, to aid the rapid dissemination of reviews, along with regular articles, all work will now be available on FirstView within approximately two to three weeks of the completion of proof corrections. FirstView is a digital publication format, and articles can be cited and quoted using the Digital Object Identifier, or doi [https:/ / www.doi.org], as the reference source. Once a doi is assigned to an article, it is considered published, not "in print," "in press," "forthcoming," or any other of a plethora of pre-publication phrases. We believe this accelerated path to publication is an invaluable tool for scholars who are actively on the job market, or perhaps seeking promotion and/or tenure, and also in other contexts for which a timely and complete scholarly dossier is indispensable. The ASR has also joined the CUP "shareable link" pilot program. Simply click on "Shareable Link" below your online article, or use an email option, to share with colleagues and friends. Anyone receiving the link will be able to freely

African Studies Review, Volume 61, Number 2 (July 2018), pp. 1-7 
read the content. As responsible social sharing plays an increasingly important role in the academy, we also invite you to familiarize yourself with the Cambridge University Press content sharing policy [https://www.cambridge. org/core/services/open-access-policies/social-sharing].

The ASR's web portal contains a number of valuable new additions, all with a view to improving the communications between contributors and the editorial team. We recently launched a new Frequently Asked Questions (FAQ) [https://www.cambridge.org/core/journals/african-studies-review/ information/faqs], drawing on input from our experienced Editorial Review Board. The FAQ is directed at prospective authors as well as returning contributors, and it covers a vast range of recurring issues. Among other topics, we address the type of scholarship that interests the ASR and its readership, the mode of online submission, the importance of addressing an interdisciplinary African studies audience, and best practices for doublemasked redacted anonymous peer review (formerly known as double-blind). With the gracious assistance of former ASA President Catharine Newbury, Professor Emerita at Smith College, we provide careful guidance on how to write an effective abstract [https://www.cambridge.org/core/journals/ african-studies-review/information/writing-an-effective-abstract]. A wellcomposed abstract is key to the successful dissemination of your research. Many articles are only ever read in abstract form! And if you're wondering why reviewing takes so long, what it entails, and how to respond to reviews, we invite you to begin here. We have all navigated the peer review process, and these FAQs draw on a wealth of experience and knowledge.

With the engagement of Ms. Salucka, we have expanded our capacity in a number of ways, including establishing the Pipeline for Emerging African Studies Scholars (PEASS) workshops [https://africanstudies.org/peassworkshops/]. As part of this capacity-building and the second of four initiatives, throughout 2018 the editorial management will be conducting a quality control survey with recent former contributors and reviewers. We are interested to learn about your experience submitting original work for review, and about your involvement in the peer review process either as a manuscript reviewer or as a book reviewer. Ms. Salucka will be contacting a broader selection of contributors from the past several years, asking questions about the process of submission, the quality of peer review feedback, and the experience of editorial engagement, copy editing, and the proof stage. We ask for your candor and frankness, and we welcome any positive feedback or thoughtful suggestions for improvement as we strive to meet the diverse needs of the ASA's membership and of Africanist scholars around the globe.

A third improvement in $A S R$ management is the rollout of the new editorial workflow within ScholarOne, the online web-based platform for journal submissions. Beginning in early 2018 with an expanded editorial team, we have created a workflow that optimizes response times and review feedback. All new submissions are now subjected to an initial Managing Editor (ME) review for consistency with manuscript requirements, and any manuscripts not conforming are returned without editorial review. 
Manuscripts are then reviewed by the Editor-in-Chief (EIC) to ascertain if the matter is topical and meets the general interests of the readership before moving on to a full review by the editorial team. Each week the editors review all new manuscripts, along with others that have been revised, and make recommendations. New manuscripts recommended for further peer review are assigned to a Responsible Editor. Ideally, we hope to receive at least three manuscript evaluations before we proceed to a decision about the submission's suitability for publication. Regardless of the decision, the manuscript moves through the pipeline, and the final actions are taken by the EIC and affirmed by ME. This new review workflow ensures that all manuscripts are evaluated on average by six to eight reviewers with differing disciplinary and thematic skills and interests, as they move through the process. Our objective is to provide rigorous and critical feedback and to shape scholarly products to appeal to the broad and diverse audience of the ASA.

The final procedural change is designed to counteract a more troubling matter. There is perhaps no greater scourge in the academy than plagiarism. Plagiarism affects all scholarly journals and disciplines, but fortunately resources and tools to combat it are rapidly improving. Because the highly specialized and focused research agendas of Africanists are no less affected by plagiarism than other fields and subfields, the editors in March 2018 endorsed the adoption of iThenticate [www.ithenticate.com], a leading plagiarism detection tool, from iParadigms LLC, under contract with our publisher, Cambridge University Press [www.cambridge.org]. Over the next several months we will be rolling out the implementation of iThenticate, following best practices and professional academic standards employed by CUP and the Committee on Publishing Ethics [https://publicationethics.org]. iThenticate also allows for integration with manuscript tracking systems, such as ScholarOne. The software is flexible and adaptable to the needs of Africanists and allows us to set threshold percentages, which when reached alert editors to possible issues prior to sending out submissions for review. In tandem with this new software, the editorial team is currently developing a set of practices for dealing with any possible suspicions of plagiarism, including a response opportunity for the imputed plagiarist, and further escalation options in the event that an instance or instances of plagiarism are detected. We welcome the input of those with experience in these matters.

Our overall objective at the ASR is to attract, review, and publish the best new research and scholarship in African studies. With these reforms, and with your support and engagement, we will achieve this goal and ensure the integrity of the final product of the flagship journal of the African Studies Association (USA).

The articles in this issue encompass a broad array of disciplines and interdisciplinary sites of research, ranging from sociocultural anthropology, conservation, music, education, and knowledge regimes to developmental geography and climatology, political science, medicine and health, and history. Our contributors explore case studies in Ghana, Kenya, Niger, Somalia, and Zimbabwe, as well as the broader African continent and beyond, to Europe and North America. 
Our first pair of articles grapples with bedrock issues in interdisciplinary African studies, namely the decolonization of knowledge and the theorization of patron-client relations. We begin with Diana Jeater's investigation of how university cultures in the Global North generate hegemonic definitions of "knowledge" and "good research" in her article, "Academic Standards or Academic Imperialism? Zimbabwean perceptions of hegemonic power in the global construction of knowledge." [https://doi.org/10.1017/ asr.2017.132] Jeater asks provocatively, who gets to represent the "African perspective"? The answer, which she finds in interviews with senior university research managers in Zimbabwe, is that Africans play a decreasing role. She argues that paying greater attention to how academic standards undervalue the predominant positivist research orientation in southern African universities, and more specifically, to who has the power to validate knowledge and knowledge systems, is vital.

With Lisa Mueller's "Personal Politics without Clientelism? Interpreting Citizen-Politician Contact in Africa," [https://doi.org/10.1017/asr.2017.131] we travel to Niger to investigate the modalities of clientelism in the Sahel. Mueller defines clientelism as "personal contact between citizens and politicians in which citizens request selective rather than public goods in exchange for political loyalty" (Mueller 2018:28, emphasis added). Previous survey assessments, such as the Afrobarometer, suggest personal contact is mostly clientelistic. By contrast, Mueller finds that original open-ended questionnaires in Niger point to the programmatic nature of citizen requests. Nigeriens visit and interface with politicians in an uncharacteristically highly personalized manner, reflecting an adaptation to limitations, not the circumvention of formal channels for the purpose of distributing patronage.

The second pair of articles examines ethnic, familial, socioeconomic, and political ties and conflicts arising from these relations. Mohamed Haji Ingiriis explores the powerful contemporary legacy of the Somali military regime of Mohamed Siad Barre (1969-1991). In "From Clan-States to ClanStates: The Return to Pre-Colonial Clan Republics in Somalia," [https:/ / doi.org/10.1017/asr.2017.144] Ingiriis is interested in what he calls the paradox that Somalia both emerged from pre-colonial clan-states and finds itself today still mired in clano-territorial conflicts which echo pre-colonial disputes. An array of primary sources points to how an ideological urgency to avert a return to power of one clan in the form of a military regime has given rise to inter-clan terror and the collapse of power- and resourcesharing arrangements. Ingiriis sees Somalia reverting to a shadow of its precolonial sultanic clan-era identity.

On the other side of the continent, Kaderi Noagah Bukari, Papa Sow, and Jürgen Scheffran, offer a new account of the omnipresence of tensions, conflicts, and quotidian relations between farmers and herders in Ghana. In "Cooperation and Co-Existence Between Farmers and Herders in the Midst of Violent Farmer-Herder Conflicts in Ghana," [https://doi. org/10.1017/asr.2017.124] Bukari, Sow, and Scheffran contend that while there are episodic outbreaks of extreme violence in different parts of Ghana 
between Fulani pastoralists and sedentary farmers, day-to-day, and year-toyear, the communities co-exist and cooperate effectively and peacefully. As "cultural neighbors" during conflict and peace, cooperation in the Asante Akim North and Gushiegu districts is expressed through commonplace interactions that build trust, such as adoption, trade, and marriage, and involves many more stakeholders beyond the herders and farmers, such as chiefs, government officials, and what the authors refer to as "opinion leaders" (Bukari et al. 2018:96). Bukari, Sow, and Scheffran's essay is an important contribution to the theorization of cultural neighborhood and everyday peace; they remind us that cooperation is an "enduring hallmark" (Bukari et al. 2018:85) and that conflict is highly exceptional.

The final cluster of five papers all focus on postcolonial and contemporary Kenya, and we have brought them together as a forum in honor of two outgoing editors, Elliot Fratkin and Richard Waller, both renowned scholars of Kenya. Elliot and Richard have been loyal stalwarts of the ASR for over a decade, in various capacities, and preeminent stewards of African studies more generally. Elliot served as co-editor with Sean Redding for the past seven years, until December 2017, and Richard has served as co-editor of book reviews with John Lemly since 2012. Because both Richard and Elliot are Kenya specialists, it seemed a fitting tribute to their tireless service to the profession and to the ASA to dedicate this Kenya Studies forum to them. We are very pleased to have short reflections on Elliot from his co-editor, Sean Redding, and on Richard by his co-editor John Lemly, and also by one of the many younger scholars he has mentored over the years, Paul Ocobock. Paul Ocobock and Bettina Ng'weno provide a short introduction [https://doi.org/10.1017/asr.2018.47] to the Forum on Post-Colonial and Contemporary Kenya dedicated to Elliot Fratkin and Richard Waller.

The first of five articles takes us on an excursion into the concealed world of the contemporary Kenyan music scene. Nairobi hip hop's objective is the instantiation of a worthy political space, one that also seeks a cure for Kenya's deeply flawed polity. RaShelle Peck's "Love, Struggle, and Compromises: The Political Seriousness of Nairobi Underground Hip Hop," [https://doi.org/10.1017/asr.2017.143] explores the characteristics of Nairobi's underground hip hop. Peck is interested in documenting the notion of "political seriousness," both her concept of it and a colloquial viewpoint that holds that music must be "substantive, thought-provoking, socially critical" (Peck 2018:111). She identifies four prevailing serious themes, namely: the gendered legacies of Mau Mau; political love; a reliance on neoliberalism; and, finally, a critique of the state. Successful and serious hip hop is never vacuous, but its objective is also an imperfect endeavor. Nairobi's artists celebrate the authenticity of a musical form that advocates for disenfranchised communities while projecting connections to an imagined global hip hop culture.

In Devin Smart's essay, entitled “'Safariland': Tourism, Development, and the Marketing of Kenya in the Post-Colonial World," [https://doi. org/10.1017/asr.2017.133] we revisit the historical role of tourism in the 
development plans of Kenya during the 1960s and 1970s, examining what this reveals about the new opportunities and constrictions that officials encountered as they repositioned the new Kenyan nation state in a rapidly changing decolonizing post-colonial world. The political economy of development and tourism and the marketing infrastructures were pivotal in the formulation and launch of a decidedly Western impression of "Kenya." Smart is interested in how these and other related factors ultimately influenced the kinds of global discourses about Kenya in its first decades of independence.

Sibel Kusimba's contribution, entitled "Money, Mobile Money, and Rituals in Western Kenya: The Contingency Fund and the Thirteenth Cow," [https://doi.org/10.1017/asr.2017.145], directs our attention to the rich social life of money and the dramatic shifts that have taken place in recent decades via the rites de passage of young boys. Kusimba describes how life cycle rituals influence the collection and distribution of different forms of currency, including land, property, personhood, animals, cash, and digital moneys. By organizing multiple forms of money relative to the phases of human life, the past, and the future, these rituals serve to manage and transfer wealth across generations with important social and moral dimensions. Her study critiques embedded assumptions about Kenya in general and Global South financial initiatives in particular.

The final two articles, both situated in the western highlands, bring us right up to the present day and highlight the explosion of political and social violence in the postcolony, a phenomenon that Jean and John Comaroff have described generally as "especially, excessively, distinctively violent and disorderly" (2006:vii). Elizabeth Pfeiffer takes us on a survey of the havoc wrought in recent Kenyan electoral cycles via the lives of those affected by HIV/AIDS in the town of Mahali, among "the most chaotic areas in Kenya" (Pfeiffer 2018:193). In "The Post-Election Violence Has Brought Shame on This Place': Narratives, Place, and Moral Violence in Western Kenya," [https://doi.org/10.1017/asr.2017.117] Pfeiffer explores the intersections of structural violence, morality, and place to theorize the notion of moral violence. Using narratives collected during ethnographic research in a "tainted," "divided and devalued" (Pfeiffer 2018:194) highway town, she suggests that when people offer moralizing sentiments, they are observing and recasting the effects of and anxieties about the prolonged violence and inequalities swamping the region.

And finally, Graham Fox zeroes in on one particular manifestation of targeted violence tied to the highly racially marked tourism industry. In "The 2017 Shooting of Kuki Gallmann and the Politics of Conservation in Northern Kenya," [https://doi.org/10.1017/asr.2017.130] Fox situates the near execution of a white Italian-Kenyan landowner, poet, and author, Kuki Gallmann, within recent critiques of community-based conservation and the politics of whiteness in Kenya. As Smart's article observes, particular discourses about Kenya and conservation resided at the heart of globally-oriented conservation strategies in the 1960s and '70s. Fox's argument 
amplifies this, demonstrating how conservation ideologies have enabled white landowners to consolidate influence in Laikipia County and neighboring regions via proprietary private trust arrangements. Trusts are now widely feared by pastoralists and others, insofar as they contribute to land shortages and trigger violence. Echoing some of the explanations of violence in Bukari et al., Fox contends that the pastoralists implicated in conflicts are themselves subjected to "livelihood stressors" aggravated by the encroachment of white landowners' conservation strategies.

As always, we conclude our issue with a fascinating array of review essays and reviews. Abigail Celis [https://doi.org/10.1017/asr.2018.21] reviews two new films made by African women filmmakers. We are also pleased to review The Faces of Change Collection [https://doi.org/10.1017/asr.2018.11], a remarkable collection of heritage ethnographic films. We also feature two further film reviews and fourteen book reviews. All the essays in this issue originated under the previous editorial team led by Sean Redding and Elliot Fratkin and we thank them both again for their insightful feedback, careful editorial guidance, and intellectual generosity.

Benjamin N. Lawrance

\section{Reference}

Comaroff, Jean, and John Comaroff, eds. 2006. Law and Disorder in the Postcolony. Chicago: The University of Chicago Press. 